\title{
PENGARUH WAKTU INKUBASI DAN KONSENTRASI SUKROSA TERHADAP KARAKTERISTIK MINUMAN PROBIOTIK DARI WHEY HASIL SAMPING KEJU
}

\author{
EFFECT OF INCUBTION TIME AND SUCROSE CONCENTRATION ON PROBIOTIC \\ DRINK CHARACTERISTIC FROM WHEY A CHEESE BY-PRODUCT
}

\author{
Edhi Nurhartadi $^{1}$, Asri Nursiwi ${ }^{1)}$, Rohula Utami ${ }^{1)}$, Erina Widayani ${ }^{1)}$ \\ ${ }^{1)}$ Program Studi Teknologi Pangan, Fakultas Pertanian, Universitas Sebelas Maret, Surakarta \\ Jl. Ir. Sutami 36A Kentingan Jebres Surakarta 57126 \\ Email : edhi.nr@staff.uns.ac.id
}

Diserahkan [24 Mei 2018]; Diterima [5 Juli 2018]; Dipublikasi [31 Agustus 2018]

\begin{abstract}
Whey is a cheese by product that has potential to be developed into fermented drink because inside it is still lactose, proteins and minerals. This study aims to determine the effect of variations in incubation time and sucrose concentration on the probiotic drink characteristics made from whey. This study uses Completely Randomized Design (CRD) with two factors, variation of incubation time (24 and 36 hours) and sucrose concentration of $(8 \% ; 10 \% ; 12 \%)$ on the probiotic whey drink. Probiotic starter cultures used are Lactobacillus acidophillus and Bifidobacterium longum IFO ATCC 1395115708 with ratio of 1: 1. Analysis was performed on viscosity, lactic acid levels, pH, antioxidant activity, total lactic acid bacteria and sensory characteristics. The results showed that the selected formula based on hedonic test is probiotic whey drink with 36-hour incubation time and $12 \%$ sucrose concentration. Probiotic whey drink has characteristics namely viscosity 6.578 $c P, 0.453 \%$ lactic acid levels, $\mathrm{pH} 4.36$, the antioxidant activity of $19.409 \%$, and total lactic acid bacteria $7.4 x$ $10^{9}$ cells $/ \mathrm{ml}$.
\end{abstract}

Keywords: fermentation, incubation time, probiotic, sucrose concentration, whey

\section{ABSTRAK}

Whey merupakan hasil samping keju yang mempunyai potensi untuk dikembangkan menjadi minuman fermentasi karena di dalamnya masih terdapat laktosa, protein dan mineral. Penelitian ini bertujuan untuk mengetahui pengaruh variasi waktu inkubasi dan konsentrasi sukrosa terhadap karakteristik minuman probiotik berbahan dasar whey. Penelitian ini menggunakan Rancangan Acak Lengkap (RAL) dengan dua faktor, variasi waktu inkubasi (24 dan 36 jam) dan konsentrasi sukrosa $(8 \% ; 10 \% ; 12 \%)$ pada minuman whey probiotik. Kultur starter probiotik yang digunakan adalah bakteri Lactobacillus acidophillus IFO 13951 dan Bifidobacterium longum ATCC 15708 dengan rasio 1:1. Analisis dilakukan pada viskositas, kadar asam laktat, pH, aktivitas antioksidan, total bakteri asam laktat dan sensori. Hasil penelitian menunjukkan bahwa formula yang paling disukai panelis yaitu minuman whey probiotik dengan waktu inkubasi 36 jam dan konsentrasi sukrosa $12 \%$. Minuman whey probiotik yang paling disukai mempunyai karakteristik yaitu viskositas $6,578 \mathrm{cP}$, kadar asam laktat $0,453 \%, \mathrm{pH} 4,36$, aktivitas antioksidan 19,409\%, dan total bakteri asam laktat 7,4 x 10 $\mathrm{sel} / \mathrm{ml}$.

Kata kunci: fermentasi, konsentrasi sukrosa, waktu inkubasi, minuman whey probiotik

\section{PENDAHULUAN}

Whey merupakan hasil samping yang dihasilkan dari satu tahapan proses pembuatan keju. Setiap produksi $1 \mathrm{~kg}$ keju dari 10 liter susu sapi segar akan dihasilkan 8-9 liter whey. Komponen utama yang terdapat pada protein whey adalah $\beta$ lactoglobulin $(\beta-\lg )$ dan $\alpha$-lactalbumin $(\alpha-$ la), karena kedua protein ini mempunyai proporsi berkisar $80 \%$ dari seluruh protein whey (Rachmawati, 2010). Menurut Soekotjo (2003) whey dari keju mengandung kurang lebih 85-90\% volume susu dan lebih dari setengahnya adalah bahan padat susu,
$6 \%$ dari padatan dalam whey, mengandung $10 \%$ protein, $72 \%$ karbohidrat, $1 \%$ lemak, dan $8,2 \%$ abu. Mineral dalam whey antara lain adalah kalsium, fosfor, natrium, dan kalium. Di dalam whey mengandung laktosa yang cukup tinggi, sehingga whey dapat dimanfaatkan sebagai bahan baku pembuatan produk minuman yang menggunakan proses fermentasi.

Untuk memberikan nilai tambah pada whey adalah melalui proses fermentasi menggunakan mikroba probiotik. Proses fermentasi akan menghasilkan produk yang memiliki fungsi kesehatan, bercitarasa khas, 
dan praktis (Rahmawati, 2010). Minuman probiotik mengandung bakteri probiotik yang bermanfaat dan turut berfungsi dalam pencernaan manusia, yaitu Bifidobacterium yang banyak dijumpai di saluran pencernaan manusia dan hewan secara alamiah. Bakteri lain yang termasuk bakteri probiotik dan sudah melalui uji klinis adalah Lactobacillus casei dan L. acidophilus (Soekotjo, 2003). Produk pangan dikatakan sebagai probiotik harus mengandung bakteri probiotik dengan jumlah minimal $10^{7} \mathrm{cfu} / \mathrm{ml}$. Strain $L$. acidophilus memiliki banyak kegunaan di antaranya sebagai kultur starter pada produk olahan susu, untuk terapi yang terkait dengan keseimbangan aktivitas mikroba usus, digunakan dalam fermentasi makanan, dan sebagai probiotik pada suplemen diet (Sanders and Klaenhammer, 2001).

Penambahan sukrosa akan mempengaruhi pertumbuhan bakteri probiotik yang ada dalam minuman dan aktivitasnya dalam memanfaatkan komponen karbohidrat yang ada di dalam susunan bahan baku produk minuman fermentasi whey. Sukrosa merupakan salah satu faktor yang mampu mempengaruhi pertumbuhan bakteri asam laktat dan berpengaruh terhadap sifat fisik dan kimia produk (Sintasari dkk, 2014). Sukrosa akan meningkatkan total padatan, memberikan rasa manis sehingga akan mempengaruhi penerimaan masyarakat terhadap minuman probiotik. Menurut penelitian Maryana (2014) penambahan sukrosa dan bakteri probiotik ke dalam whey fermentasi dapat meningkatkan mutu dari limbah whey. Pada penelitian ini whey limbah keju diolah untuk menjadi minuman probiotik dengan dilakukan variasi waktu inkubasi dan konsentrasi serta digunakan bakteri probiotik Lactobacillus acidophillus IFO 13951 dan Bifidobacterium longum ATCC 15708.

\section{BAHAN DAN METODE}

\section{Bahan}

Whey didapatkan dari industri pengolahan keju di Boyolali. Bakteri probiotik Bifidobacterium longum ATCC 15707 dan Lactobacillus acidophilus IFO
13951 dari Laboratorium Rekayasa Proses Pengolahan dan Hasil Pertanian, Program Studi Ilmu dan Teknologi Pangan, Fakultas Pertanian, Universitas Sebelas Maret Surakarta. Gula sukrosa merk "Gulaku". $\mathrm{NaOH} 0,1 \mathrm{~N}$, indikator phenolphthalein (pp) $1 \%$ trayek $\mathrm{pH} 8-10$, aquadest, larutan bufer $\mathrm{pH}$ 7,0 dan $\mathrm{pH} 4,0$. Media deMan Rogosa Sharpe (MRS) agar dan broth, larutan Nelson A dan B, arsenomolibdat, larutan standar laktosa, larutan 2,2-diphenyl-1pycrylhydrazyl (DPPH), borang dan nampan.

Alat

Perkembangbiakan bakteri probiotik: ose, bunsen, tabung reaksi, vortex, laminar air flow (Labconco), inkubator, autoklaf (Selecta), kulkas. Analisis: Laminar Air Flow (Labonco), inkubator (Selecta), autoklaf (Selecta), cawan petri, pipet, bunsen, oose, vortex, Erlenmeyer $250 \mathrm{ml}$, buret, statif, $\mathrm{pH}$ meter, pipet tetes, Erlenmeyer $100 \mathrm{ml}$, falling ball viscometer, pipet volume, propipet, kuvet, spektrofotometer UV-Vis 1240 Shimadzu, waterbath (Memmert), labu takar, tabung reaksi (Pyrex), gelas plastik, sendok kecil, nampan.

\section{Tahapan Penelitian}

\section{Pembiakan Bakteri Probiotik}

Pembiakan bakteri probiotik dilakukan setelah kultur murni didapatkan. Peremajaan menggunakan media MRS (deMan Rogosa and Sharpe) cair dalam tabung reaksi. Selanjutnya diinkubasi pada suhu $37^{\circ} \mathrm{C}$ sewaktu 24 jam dan disimpan pada suhu $4^{\circ} \mathrm{C}$. Peremajaan dilakukan hanya jika ada perlakuan.

\section{Pembuatan starter}

Pembuatan kultur starter dilakukan dengan cara menginokulasikan kultur murni yang disimpan dalam media MRS (deMan Rogosa and Sharpe) cair pada susu skim $(10 \%$ b/v) yang telah dipasteurisasi kemudian diinkubasi pada suhu $37^{\circ} \mathrm{C}$ selama 12 jam sehingga disebut dengan starter induk. Starter induk sebanyak 3\% (v/v) kemudian ditambahkan susu skim sebesar $10 \%(\mathrm{~b} / \mathrm{v})$ dan diinkubasi $37^{\circ} \mathrm{C}$ selama 12 
jam sehingga disebut starter kerja. Starter yang dibutuhkan dalam pembuatan minuman probiotik $1 \%\left(10^{8} \mathrm{cfu} / \mathrm{ml}\right)$.

\section{Pembuatan minuman probiotik}

Proses pembuatan minuman probiotik yaitu whey dipasteurisasi pada suhu $75^{\circ} \mathrm{C}$ selama 30 menit, ditambahkan sukrosa konsentrasi $8 \%, 10 \%, 12 \%$ pada suhu ruang $25^{\circ} \mathrm{C}$. Dikemas dalam wadah yang tertutup, lalu ditambahkan Lactobacillus acidophilus IFO 13951 dan Bifidobacterium longum ATCC 15707 dengan perbandingan 1\%:1\%, selanjutnya diinkubasi pada suhu $37^{\circ} \mathrm{C}$ dengan waktu inkubasi 24 dan 36 jam.

\section{Analisis}

\section{Penentuan pH}

$\mathrm{pH}$ ditentukan dengan $\mathrm{pH}$ meter pada sampel minuman probiotik whey.

\section{Kadar Asam Laktat}

Kadar asam laktat ditentukan dengan cara dititrasi dengan $\mathrm{NaOH} 0,1 \mathrm{~N}$ yang sebelumnya telah ditambahkan indikator PP $1 \%$ sebanyak 2 tetes sampai dengan warna sampelnya merah muda. Kadar asam laktat dihitung sebagai berikut :

Kadar asam laktat $(\%)=\frac{(\mathrm{N} \times \mathrm{V}) \mathrm{NaOH} \times \mathrm{BM} \text { Asam Laktat }}{\mathrm{ml} \text { bahan } \mathrm{x} 1000}$ Keterangan :

$\begin{array}{ll}\mathrm{N} \mathrm{NaOH} & =0,096 \\ \text { BM Asam Laktat }\left(\mathrm{C}_{3} \mathrm{H}_{6} \mathrm{O}_{3}\right) & =90\end{array}$

\section{Aktivitas Antioksidan}

Nilai aktivitas antioksidan minuman probiotik whey dianalisis dengan metode DPPH, absorbansi ditera dengan spektrofotometer pada panjang gelombang $517 \mathrm{~nm} .5 \mathrm{ml}$ methanol ditambah $1 \mathrm{ml}$ DPPH digunakan sebagai blanko. Aktivitas antioksidan dinyatakan dalam bentuk persen penangkapan radikal DPPH dan dihitung dengan persamaan $\%$ aktivitas antioksidan $=\frac{\text { (absorbansi kontrol-absorbansi sampel) }}{\text { absorbansi kontrol }} \times 100 \%$

\section{Penentuan Viskositas}

Penentuan viskositas dilakukan dengan menggunakan viskometer, yaitu sampel dimasukkan ke dalam viskometer sampai tanda, bola dimasukkan ke dalam viskometer kemudian dihitung waktu bola jatuh sampai dasar. Viskositas minuman probiotik whey dihitung berdasarkan persamaan :

Viskositas $=\mathrm{K} \times(\rho \mathrm{t}-\rho) \mathrm{t}$

Keterangan :

$\mathrm{K}=$ Viscometer Constanta $(0,2816)$

$\rho \mathrm{t}=$ berat jenis bola

$\rho=$ berat jenis bahan

$\mathrm{t}=$ waktu yang dibutuhkan bola sampai dasar

\section{Total Bakteri Probiotik}

Perhitungan total bakteri probiotik dengan dihitung bakteri di bawah mikroskop menggunakan haemocytometer.

\section{Analisis Sensoris}

Analisis sensoris dengan uji tingkat kesukaan panelis, digunakan 30 panelis tidak terlatih, setiap panelis diminta untuk menilai sampel, dengan parameter yang diuji yaitu warna, aroma, rasa, kekentalan, dan overall.

\section{Analisis Data}

Rancangan percobaan yang digunakan dalam penelitian ini adalah Rancangan Acak Lengkap (RAL) dengan faktof variasi waktu inkubasi dan variasi penambahan gula minuman probiotik berbahan dasar whey limbah keju dengan masing-masing perlakuan dilakukan tiga kali ulangan sampel dan dua kali ulangan analisis. Data analisis yang diperoleh dianalisis secara statistik dengan metode One Way ANOVA melalui program SPSS 17.0. Jika menunjukkan hasil yang signifikan maka dilanjutkan dengan uji beda nyata menggunakan analisis Duncan's Multiple Range Test (DMRT) pada taraf signifikansi $\alpha=0,05$.

\section{HASIL DAN PEMBAHASAN}

Penelitian ini menggunakan whey sebagai bahan dasar dengan variasi konsentrasi sukrosa $(8 \%, 10 \%, 12 \%)$ dan waktu inkubasi (24 dan 36 jam). Penambahan sukrosa pada minuman 


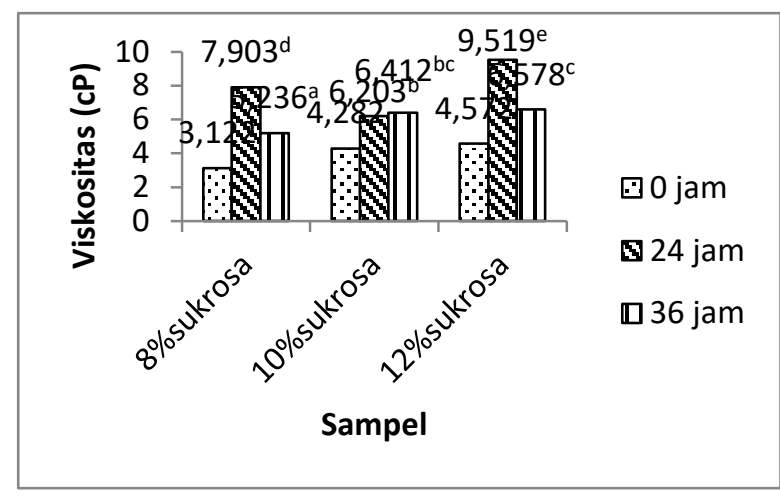

Gambar 1. Viskositas minuman probiotik whey keju

probiotik whey keju berpotensi sebagai penambah cita rasa. Selain itu sukrosa juga dimanfaatkan sebagai sumber energi bagi bakteri probiotik pada minuman probiotik whey keju. Pada penelitian ini pengujian yang dilakukan meliputi analisis sensoris, karakteristik fisik (viskositas), dan kimia (kadar asam laktat, $\mathrm{pH}$, antioksidan) dan total bakteri probiotik.

\section{Viskositas}

Hasil penelitian menunjukkan bahwa terjadi peningkatan viskositas setelah fermentasi. Perbedaan antar sampel sebelum dan sesudah fermentasi dapat dilihat pada Gambar 1.

Pada penambahan konsentrasi sukrosa $8 \%, 10 \%$, dan $12 \%$ dengan waktu inkubasi 24 jam dan 36 jam menunjukkan bahwa terjadi perbedaan viskositas. Hampir tidak adanya kasein pada whey, menyebabkan penggumpalan pada minuman probiotik dari whey keju ini menjadi bervariasi, sedangkan pada penelitian Herawati (2009) viskositas dari produk susu diakibatkan terjadinya penggumpalan kasein karena rendahnya keasaman akibat aktivitas kultur bakteri.

Ditinjau dari konsentrasi sukrosa yang ditambahkan terlihat bahwa viskositas meningkat seiring dengan peningkatan konsentrasi sukrosa. Hal ini sesuai dengan penelitian Sintasari (2014), viskositas akan meningkat dengan semakin tingginya konsentrasi penambahan sukrosa dan susu skim. Semakin tinggi perlakuan penambahan sukrosa dan susu skim maka nilai total padatan terlarutnya juga semakin tinggi. Peningkatan sukrosa dan susu skim, menyebabkan jumlah total padatan terlarut (TPT) yang dihasilkan akan semakin banyak pula. Sewaktu proses fermentasi sukrosa dan laktosa akan dirombak menjadi asam laktat oleh kultur starter dalam jumlah besar. Sisa sukrosa, laktosa dan asam-asam organik inilah yang akan terhitung sebagai total padatan terlarut. Komponen terlarut yang semakin besar dalam suatu larutan akan meningkatkan viskositas.

Total padatan terlarut semakin besar dalam suatu larutan akan meningkatkan viskositas. Sejalan dengan penelitian Susanto dkk (2011) yang menyatakan bahwa komponen sukrosa yang ditambahkan menyebabkan terjadinya peningkatan kekentalan (viskositas). Peningkatan total padatan yang terlarut akan menyebabkan peningkatan viskositas minuman probiotik whey keju. Menurut Sintasari (2014), komponen padatan terlarut yang semakin besar dalam suatu larutan akan meningkatkan viskositas bahan.

\section{Kadar Asam Laktat}

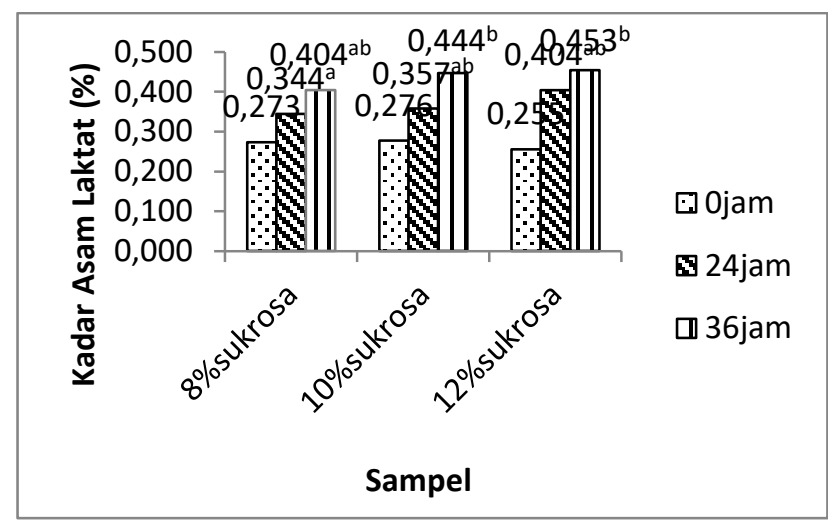

Gambar 2. Kadar asam laktat minuman probiotik whey keju

Asam laktat pada minuman probiotik dari whey limbah keju dihasilkan melalui fermentasi bakteri Lactobacillus acidophilus IFO 13951 dan Bifidobacterium longum ATCC 15707 dengan memanfaatkan sukrosa dan laktosa yang ditambahkan pada minuman probiotik tersebut. Pemecahan gula dalam sel bakteri probiotik akan menghasilkan energi untuk aktivitas bakteri probiotik sehingga dihasilkan asam laktat. Hasil penelitian (Gambar 2) menunjukkan bahwa setelah fermentasi terjadi peningkatan kadar asam laktat. Pada penambahan konsentrasi sukrosa 8\%, 10\%, 
dan $12 \%$ semakin tinggi penambahan sukrosa maka kadar asam laktat pada minuman probiotik juga semakin tinggi, begitu pula semakin waktu waktu inkubasi maka semakin tinggi kadar asam laktat yang dihasilkan, hal ini dikarenakan terjadi metabolisme bakteri asam laktat yaitu bakteri Lactobacillus acidophillus IFO 13951 dan Bifidobacterium longum ATCC 15707 yang menghasilkan asam laktat. Asam laktat sebagai produk akhir metabolisme bakteri asam laktat menyebabkan peningkatan keasaman produk minuman whey fermentasi. Peningkatan keasaman menyebabkan peningkatan konsentrasi ion hidrogen. Peningkatan ion hidrogen menyebabkan turunnya $\mathrm{pH}$.

Yudianto dkk (2012) menambahkan bahwa waktu fermentasi akan mempengaruhi seberapa banyak gula yang diubah menjadi asam laktat. Bakteri asam laktat memanfaatkan gula sebagai sumber energi, pertumbuhan dan menghasilkan metabolit berupa asam laktat sewaktu proses fermentasi. Asam laktat yang terbentuk ini dipengaruhi oleh penambahan sukrosa. Pada tahap pertama sukrosa akan dipecah menjadi asam piruvat melalui Jalur Embden Meyerhof-Parnas (EMP) (Lee, 1996). Pada tahap kedua fermentasi asam piruvat akan diubah menjadi asam laktat (Fardiaz, 1988). Yusmarini dan Effendi (2004) menyatakan penambahan beberapa jenis karbohidrat dalam pembuatan yoghurt yaitu laktosa, sukrosa dan glukosa sebagai sumber karbon, memberikan pengaruh terhadap $\mathrm{pH}$, kadar asam laktat dan kandungan protein.

Nilai pH

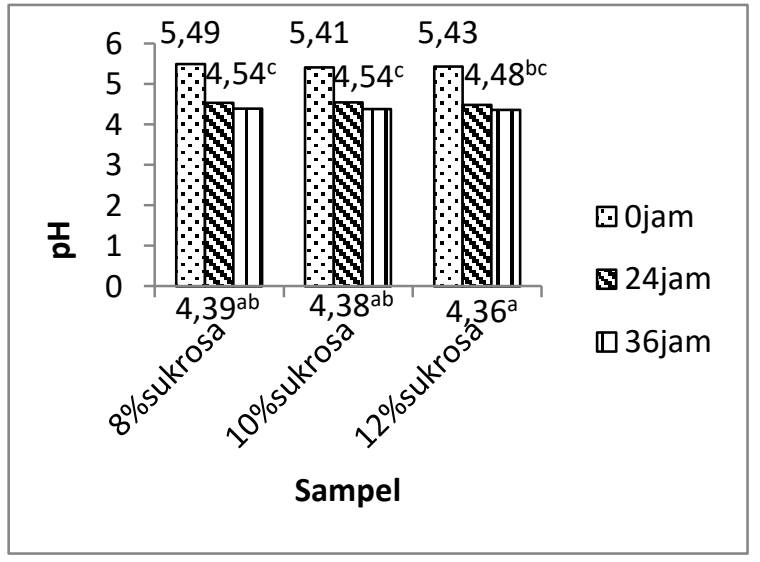

Gambar 3. Nilai $\mathrm{pH}$ minuman whey probiotik
Pada Gambar 3. dapat dilihat bahwa $\mathrm{pH}$ minuman whey probiotik untuk dengan waktu inkubasi 24 jam, konsentrasi sukrosa $8 \%$, $10 \%$, dan $12 \%$ menunjukkan tidak saling berbeda nyata namun berbeda nyata dengan sampel waktu inkubasi 36 jam, konsentrasi sukrosa $8 \%, 10 \%$, dan $12 \%$. Hal ini disebabkan karena pengaruh variasi konsentrasi sukrosa dan waktu inkubasi. Pada penambahan konsentrasi sukrosa $8 \%$, $10 \%$, dan $12 \%$ dapat dilihat bahwa semakin tinggi penambahan sukrosa maka $\mathrm{pH}$ minuman probiotik semakin menurun, begitu juga dengan waktu inkubasi 24 jam dan 36 jam, semakin lama waktu inkubasi maka $\mathrm{pH}$ minuman probiotik semakin menurun. Hal ini dikarenakan terjadi metabolisme bakteri Lactobacillus acidophillus IFO 13951 dan Bifidobacterium longum ATCC 15707 menghasilkan asam laktat, dimana sukrosa yang ditambahkan digunakan bakteri sebagai sumber energi untuk metabolismenya yang dapat meningkatkan kadar asam laktat sehingga menurunkan $\mathrm{pH}$. Hal ini diduga karena peningkatan jumlah asam organik yang merupakan hasil metabolisme dari bakteri asam laktat yang ada pada produk minuman whey fermentasi. Yang (2000) menyatakan bahwa, fermentasi yang melibatkan bakteri asam laktat ditandai dengan peningkatan jumlah asam-asam organik yang diiringi dengan penurunan $\mathrm{pH}$.

\section{Aktivitas Antioksidan}

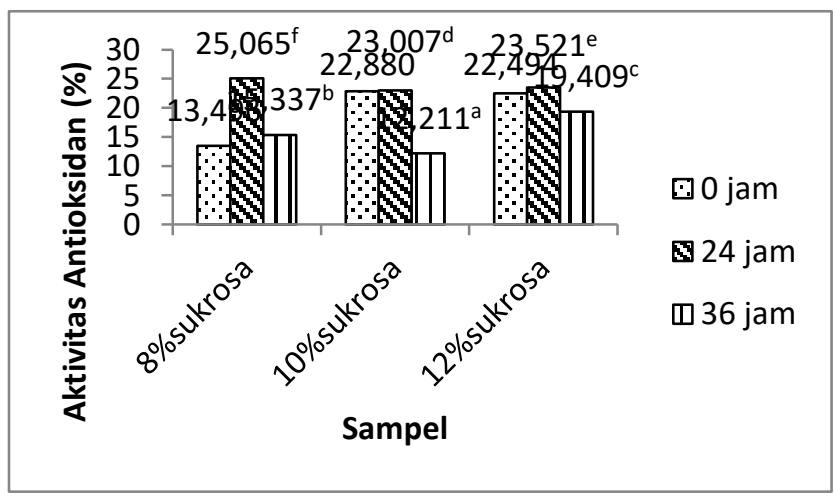

Gambar 4. Aktivitas antioksidan minuman whey probiotik

Aktivitas antioksidan tertinggi dihasilkan pada minuman probiotik whey keju dengan waktu inkubasi 24 jam, konsentrasi sukrosa $8 \%$ yaitu $25,065 \%$. Sedangkan aktivitas antioksidan sebelum 
Tabel 1. Hasil analisis sensoris minuman whey probiotik

\begin{tabular}{cccccc}
\hline $\begin{array}{c}\text { Waktu inkubasi (jam) } \\
\text { :Konsentrasi sukrosa } \\
(\%)\end{array}$ & Warna & Aroma & Rasa & Kekentalan & Overall \\
\hline 24 jam : $8 \%$ & $3,24^{\mathrm{a}}$ & $2,92^{\mathrm{a}}$ & $3,00^{\mathrm{ab}}$ & $3,04^{\mathrm{a}}$ & $2,88^{\mathrm{a}}$ \\
24 jam : $10 \%$ & $3,16^{\mathrm{a}}$ & $3,08^{\mathrm{ab}}$ & $3,56^{\mathrm{c}}$ & $3,20^{\mathrm{a}}$ & $3,48^{\mathrm{b}}$ \\
24 jam : $12 \%$ & $3,12^{\mathrm{a}}$ & $3,28^{\mathrm{ab}}$ & $3,48^{\mathrm{bc}}$ & $3,08^{\mathrm{a}}$ & $3,60^{\mathrm{b}}$ \\
36 jam : $8 \%$ & $3,08^{\mathrm{a}}$ & $3,12^{\mathrm{ab}}$ & $2,84^{\mathrm{a}}$ & $3,12^{\mathrm{a}}$ & $2,88^{\mathrm{a}}$ \\
36 jam :10 \% & $3,36^{\mathrm{a}}$ & $3,40^{\mathrm{b}}$ & $3,48^{\mathrm{bc}}$ & $3,12^{\mathrm{a}}$ & $3,44^{\mathrm{b}}$ \\
36 jam: $12 \%$ & $3,04^{\mathrm{a}}$ & $3,04^{\mathrm{ab}}$ & $4,12^{\mathrm{d}}$ & $3,20^{\mathrm{a}}$ & $3,72^{\mathrm{b}}$ \\
\hline${ }^{*}$ ) Notasi huruf yang sama pada kolom yang sama menunjukkan tidak berbeda nyata pada $\alpha=0,05$. & \\
1=sangat tidak suka; 2=tidak suka; 3=netral; 4=agak suka; 5=sangat suka &
\end{tabular}

fermentasi yaitu $13,496 \%$. Hasil penelitian ini menunjukkan bahwa terjadi peningkatan aktivitas antioksidan setelah fermentasi.

Lin and Chang (2000) menyatakan bahwa Bifidobacterium longum ATCC 15708 dan Lactobacillus acidophilus ATCC 4356 dapat memberikan efek antioksidan yaitu dalam menghambat peroksidasi asam linoleat. Menurut Hatanaka et al. (1987) Bifidobacteria memproduksi vitamin C yang merupakan antioksidan. Asam askorbat bersifat sangat sensitif terhadap pengaruh luar penyebab kerusakan seperti suhu, oksigen, dan katalisator logam. Asam askorbat mudah teroksidasi menjadi Ldehidroaskorbat yang masih mempunyai keaktifan sebagai vitamin C. Asam Ldehidroaskorbat secara kimia sangat labil dan dapat mengalami perubahan lebih lanjut menjadi asam L-diketogulonat yang tidak memiliki keaktifan vitamin C (Pertiwi dkk, 2014).

\section{Total Bakteri Probiotik}

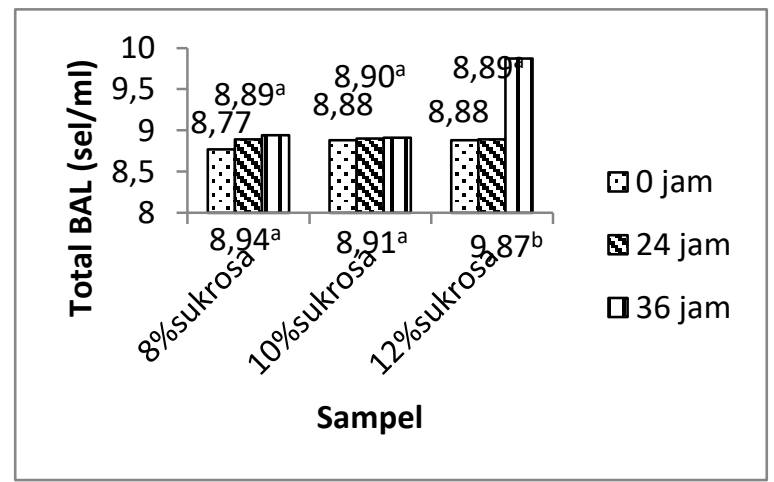

Gambar 5. Total bakteri probiotik (log sel/ml) minuman probiotik whey keju

Jumlah bakteri probiotik tertinggi terdapat pada waktu inkubasi 36 jam, konsentrasi $12 \%$ yaitu $7,4 \times 10^{9} \mathrm{sel} / \mathrm{ml}(9,87$ $\log$ sel/ml) dan jumlah bakteri terendah terdapat pada waktu inkubasi 24 jam, konsentrasi $8 \%$ dan $12 \%$ yaitu $7,7 \times 10^{8}$ $\mathrm{sel} / \mathrm{ml}(8,89 \log \mathrm{sel} / \mathrm{ml})$. Jumlah tersebut sudah memenuhi standar internasional untuk minuman probiotik yaitu minimal $10^{7} \mathrm{sel} / \mathrm{ml}$ (Davidson et al., 2000). Peningkatan dan penurunan bakteri probiotik dipengaruhi oleh antara lain jumlah nutrisi relatif tinggi (terutama gula), proses fermentasi (suhu dan waktu inkubasi), dan sinergi antar bakteri probiotik.

\section{Analisis Sensoris}

Dari hasil analisis sensoris yang dilakukan oleh panelis (Tabel 1) diketahui bahwa minuman whey probiotik yang paling disukai panelis adalah dengan perlakuan waktu inkubasi 36 jam dan konsentrasi sukrosa $12 \%$. Hal ini sesuai dengan Winarno (2004) yang menyatakan bahwa adanya sukrosa dapat meningkatkan cita rasa pada bahan makanan. Rasa manis dari sukrosa bersifat murni sebab tidak meninggalkan after taste pada makanan (Winarno, 2004). Penilaian panelis juga dipengaruhi oleh kekentalan minuman probiotik whey keju. Kesukaan panelis pada parameter ini yaitu pada minuman probiotik dengan waktu inkubasi 36 jam dan penambahan sukrosa 12\%. Menurut Simanjuntak dkk. (2013) semakin banyak konsentrasi gula maka viskositas akan meningkat begitu juga semakin lama waktu inkubasi maka viskositas akan meningkat. Hal ini karena terjadinya koagulasi protein sewaktu fermentasi. Menurut Sintasari (2014), kekentalan akan meningkat dengan semakin tingginya konsentrasi penambahan sukrosa dan susu skim. 


\section{KESIMPULAN}

Berdasarkan hasil penelitian yang telah dilakukan diperoleh kesimpulan bahwa waktu inkubasi dan penambahan sukrosa berpengaruh terhadap karakteristik fisik dan kimia minuman probiotik whey keju yaitu semakin waktu inkubasi viskositas turun dari $9,519 \%$ menjadi $6,578 \%$, kadar asam laktat naik dari $0,404 \%$ menjadi $0,453 \%, \mathrm{pH}$ turun dari 4,48 menjadi 4,36, aktivitas antioksidan turun dari $23,521 \%$ menjadi $19,409 \%$, kadar laktosa turun dari 19,448\% menjadi $17,951 \%$, dan total bakteri probiotik naik dari $7,7 \times 10^{8} \mathrm{sel} / \mathrm{ml}$ menjadi $7,41 \times 10^{9}$ $\mathrm{sel} / \mathrm{ml}$. Semakin tinggi penambahan sukrosa nilai viskositas naik dari $7,903 \%$ menjadi 9,519\%, kadar asam laktat naik dari 0,404\% menjadi $0,453 \%$, nilai $\mathrm{pH}$ turun dari 4,54 menjadi 4,48, aktivitas antioksidan turun dari $25,065 \%$ menjadi 23,521\%, kadar laktosa naik dari $15,667 \%$ menjadi $17,951 \%$, dan total bakteri probiotik naik dari $8,7 \mathrm{x}$ $10^{8} \mathrm{sel} / \mathrm{ml}$ menjadi 7,4 x $10^{9} \mathrm{sel} / \mathrm{ml}$. Minuman probiotik whey keju yang disukai panelis adalah minuman probiotik whey keju dengan waktu inkubasi 36 jam, penambahan sukrosa sebanyak $12 \%$.

\section{DAFTAR PUSTAKA}

Adriani, L. 2005. Bakteri Probiotik sebagai Starter dan Implikasi Efeknya terhadap Kualitas Yoghurt, Ekosistem Saluran Pencernaan dan Biokimia Darah Mencit. Disertasi Program Pasca Sarjana. Universitas Padjajaran. Bandung.

Almeida, K. E., Tamime, A.Y. and Oliveira, M.N. 2008. Acidification Rates of Probiotic in Minas Frescal Cheese Whey. LWT, 41: 311-316.

Anal, Anil Kumar and Harjinder Singh. 2007. Recent Advances in Microencapsulation of Probiotics for Industrial Applications and Targeted Delivery. Trends in Food Science \& Technology 18 240-251.

Anwar, M. S., A. N. Al-Baarri dan A. M. Legowo. 2012. Volume Gas, pH dan Kadar Alkohol pada Proses Produksi Bioetanol dari Acid Whey yang Difermentasi oleh Saccharomyces cerevisiae. Jurnal Aplikasi Teknologi Pangan Vol.1 No.4 Hal. 1.

Bensoltane, Ahmed and Miloud Hadadji. 2006. Growth and Lactic Acid Production by Bifidobacterium longum and Lactobacillus acidophilus in Goat's Milk. African Journal of Biotechnology Vol. 5 (6), pp. 505-509.

Buckle, K. A., R, A. Edwars, G. H. Fleet dan M. Wooten. 1987. Ilmu Pangan Terjemahan H. Purnomo. Penerbit Universitas Indonesia (UI-Press). Jakarta.

Dalev, Dimitar, Maria Bielecka, Agnieszka Troszynska, Stefan Ziajka, Gregorz Lamparski. 2006. Sensory Quality of New Probiotic Beverages Based on Cheese Whey and Soy Preparation. Polish Journal of Food and Nutrition Sciences Vol.15/56, pp.71-77.

Davidson, R.H., S.E. Duncan, C.R. Hackney, W.N. Eigel and J.W. Boling. 2000. Probiotic Culture Survival and Implications in Fermented Frozen Yogurt Characteristic. J. Dairy Sci 83 : 666-673.

De Man, J. M., 1976. Principles of Food Chemistry. The Avi Publishing Co. Inc. Westport Co.

Fardiaz. 1988. Fisiologi Fermentasi. PAU IPB bekerja sama dengan Lembaga Sumberdaya Informasi IPB p 15-16, 23.

Fardiaz, S., 1992. Mikrobiologi Pangan I. Gramedia Pustaka Utama, Jakarta.

Fatma, Soeparno, Nurliyani, Chusnul Hidayat, dan Muhammad Taufik. 2012. Optimasi Kondisi Fermentasi Whey Dangke sebagai Produk Minuman dengan Response Surface Methodology. Jurnal Agritech, Vol.32, No.03, Hal.2.

Febriasari A, Novy. 2008. Penerapan Model Gompertz pada Pertumbuhan Bakteri L. acidophilus dan B. longum di Media Adonan Es Krim (Ice Cream Mix Atau Icm) Jenis Standar. Skripsi Universitas Brawijaya, Malang.

Hatanaka, M., T. Tachiki, H. Kumagai and T. Tochikura. 1987. Distribution and Some Properties of Glutamine Synthetase and Glutamate Dehydrogenase in Bifidobacteria. Agric. Biol. Chem. 51 (1), 251-252. 
Hayati, Rita, Ainun Marliah dan Farnia Rosita. 2012. Sifat Kimia dan Evaluasi Sensori Bubuk Kopi Arabika. J. Floratek 7: $66-75$.

Helferich, W., and D. Westhoff. 1980. All About Yoghurt. Prentice-Hall, Inc., Englewood Cliffs. New Jersey.

Herawati, A. 2009. Karakteristik Fisik Granul Kultur Starter Yogurt dengan Sinbiotik Terenkapsulasi dan Aplikasinya. Departemen Ilmu Produksi dan Teknologi Peternakan. Fakultas Peternakan. Institut Pertanian Bogor.

Istiani, Y. 2010. Karakterisasi Senyawa Bioaktif Isoflavon dan Uji Aktivitas Antioksidan dari Ekstrak Etanol Tempe Berbahan Baku Koro Pedang (Canavalia ensiformis). Tesis. Program Studi Biosains. Universitas Sebelas Maret Surakarta.

Jing, H. M. Yap, P. Y. Y. Wong and D. D. Kitts. 2009. Comparison of Physicochemical and Antioxidant Properties of Egg-white Proteins and Fructose and Inulin Maillard Reaction Products. Food Bioprocess Tech., 11: 269-279.

Kailasapathy, K., I. Harmstorf and M., I. Philips. 2008. Survival of Lactobacillus acidophilus and Bifidobacterium animalis ssp.lactis Strirred Fruit Yogurts. LWT-Food Sciense and technology, volume 41, Issue 7, September 2008, Pages 1317-1322.

Kar, T. and A.K. Misra. 1999. Terapeutic Properties of Whey Used as Fermented Drink. Revista Microbiologia, 30: 163169.

Kimestri, Abio. 2013. Pengaruh Penambahan Konsentrasi Sukrosa terhadap Kandungan Laktosa, Pati, dan Sukrosa. Skripsi. Universitas Hassanudin, Makassar.

Komar, N., L. C. Hawa, dan R. Prastiwi. 2009. Karakteristik Termal Produk Keju Mozarella (Kajian Konsentrasi Asam Sitrat). Jurnal Teknologi Pertanian 10 (2): 78 - 87.

Kruszewska D, Lan J, Lorca G, Yanagisawa N, Marklinder I \& Ljungh A. 2002. Selection of Lactic Acid Bacteria as
Probiotic Strains by in Vitro Tests. Microecol Ther 29, 37-49.

Lee, B.H. 1996. Fundamental of Food Biotechnology. VCH Publishers.Inc. 3377th Avenue New Cork.

Lin, M. Y and F. J Chang. 2000. Antioxidative Effect of Intestinal Bacteria Bifidobacterium longum ATCC 15708 and Lactobacillus acidophilus ATCC 4356. Dig.Dis.Sci 45. 16171622.

Malaka, R. 2010. Pengantar Teknologi Susu. Masagena Press. Makassar.

Manfaati, Rintis, 2010. Kinetika dan Variabel Optimum Fermentasi Asam Laktat dengan Media Campuran Tepung Tapioka dan Limbah Cair Tahu oleh Rhizopus oryzae. Tesis Program Megister Teknik Kimia Universitas Diponegoro Semarang.

Maryana, Dwi. 2014. Pengaruh Penambahan Sukrosa terhadap Jumlah Bakteri dan Keasaman Whey Fermentasi dengan Menggunakan Kombinasi Lactobacillus plantarum dan Lactobacillus acidophilus. Skripsi. Fakultas Peternakan, Universitas Hasanuddin. Makassar.

Misrianti, B. 2013. Pengaruh Penambahan Sukrosa pada Pembuatan Whey Kerbau Fermentasi terhadap Penghambatan Bakteri Patogen. Skripsi. Fakultas Peternakan, Universitas Hasanuddin. Makassar.

Noriandita, Bayu, Syarifa Ummah, Umi Purwandari, Iffan Maflahah, Rahmad Fajar Sidik. 2013. Sifat Tekstural dan Analisis Sensoris Mie bebas Gluten dari Tepung Porang sebagai Efek Pregelatinisasi. Program Studi Teknologi Industri Pertanian, Fakultas Pertanian, Universitas Trunojoyo Madura.

Novianti, M. M. 2008. Kualitas Mikrobiologis Granul Effervescent Whey Bubuk yang Diperkaya Sinbiotik dengan Penambahan Effervescent Mix yang Berbeda Sewaktu Penyimpanan. Skripsi. IPB.

Oberoi, A., Anggarwal, A., \& Singh, N. 2007. Probiotic in Health - a Bug for What is bugging You. Review Artikel 
Departements of Microbiology and Medicine, 9(3): 116-119.

Parr. 2003. Hidrolika dan Pneumatika. Erlangga. Jakarta.

Pertiwi, Mentari Febrianti Darma dan Wahono Hadi Susanto. 2014. Pengaruh Proporsi (Buah:Sukrosa) dan Waktu Osmosis terhadap Kualitas Sari Buah Stroberi (Fragaria vesca L). Jurnal Pangan dan Agroindustri Vol.2 No.2 p.82-90.

Pramitaningrum, Yudhi. 2011. Pengaruh Penggunaan Beberapa Jenis Pati terhadap Karakteristik Fisikokimia dan Organoleptik Yoghurt Kental. Skripsi. Universitas Sebelas Maret. Surakarta.

Pramono, Yoyok Budi, Nurwantoro, Masykuri, dan Bambang Dwiloka. 2011. Karakteristik Mikrobiologis, Kimia, Fisik, dan Organoleptik Yoghurt dengan Penambahan Ubi Jalar Merah. DIPA Fakultas Peternakan Universitas Diponegoro. Semarang.

Purnamawati, Debbi. 2006. Kajian Pengaruh Konsentrasi Sukrosa dan Asam Sitrat terhadap Mutu Sabun Transparan. Skripsi. Fakultas Teknologi Pertanian, Institut Pertanian Bogor. Bogor.

Purwoko, T. 2007. Fisiologi Mikroba. Bumi Aksara. Jakarta.

Rahmawati, Anita. 2010. Total Bakteri Asam Laktat (BAL), Kadar Laktosa dan Keasaman Whey yang Difermentasi dengan Bifidobacterium bifidum pada Waktu Inkubasi yang Berbeda. Fakultas Peternakan, Universitas Diponegoro. Semarang.

Restiani, Yeni. 2010. Regulasi Terkait Kalim terhadap Fungsi Saluran Pencernaan. Direktorat Standarisasi Produk Pangan Badan POM RI. Food Review Vol V no 3 Maret 2010.

Retnowati, Pratiwi Anggun dan Joni Kusnadi. 2014. Pembuatan Minuman Probiotik Sari Buah Kurma (Phoenix dactylifera) dengan Isolat Lactobacillus casei dan Lactobacillus plantarum. Jurnal Pangan dan Agroindustri Vol.2 No. 2 p.70-81.

Sanders ME, Klaenhammer TR. 2001. The Scientific Basis of Lactobacillus acidophilus NCFM Functionality as a Probiotic. J. Dairy Sci. 84: 319-331.

Senditya, Meirza, Mohammad Sofyan Hadi, Teti Estiasih, Ella Saparianti. 2014. Efek Prebiotik dan Sinbiotik Simplisia Daun Cincau Hitam (Mesona palutris BL) Secara In Vivo: Kajian Pustaka. Jurnal Pangan dan Agroindustri Vol. 2 (3): 141-151.

Setioningsih, Eti, Ratna Setyaningsih, dan Ari Susilowati. 2004. Pembuatan Minuman Probiotik dari Susu Kedelai dengan Inokulum Lactobacillus casei, Lactobacillus plantarum, dan Lactobacillus acidophilus. Bioteknologi 1 (1): 1-6.

Setyaningsih, D., Anton A., dan Maya P. S. 2010. Analisis Sensori untuk Industri Pangan dan Agro. IPB Press. Bogor.

Shimakawa, Y., S. Matsubara, N. Yuki, M. Ikeda, and F. Ishikawa. 2003. Evaluation of Bifidobacterium brece Strain Yakult-fermented Soymilk as Probiotics Food. Journal Food Microbiology 81; 131-136.

Silalahi, J. 2006. Antioksidan dalam Diet dan Karsinogenesis. Cermin Dunia Kedokteran Vol. 153: 42-47.

Simanjuntak, Desi Lyan Sari, Sentosa Ginting dan Terip Karo-karo. 2013. Pengaruh Konsentrasi Gula dan Waktu Inkubasi terhadap Mutu Minuman Probiotik Sari Ubi Jalar Ungu. Jurusan Ilmu dan Teknologi Pangan, Fakultas Pertanian USU. Medan.

Sinaga, C.M., 2007. Pengaruh Konsentrasi Susu Skim dan Konsentrasi Sukrosa terhadap Karakteristik Yoghurt Jagung (Zea mays L.). Skripsi. Universitas Pasundan. Bandung.

Sintasari, Rinelda Ayu, Joni Kusnadi, dan Dian Widya Ningtyas. 2014. Pengaruh Penambahan Konsentrasi Susu Skim dan Sukrosa terhadap Karakteristik Minuman Probiotik Sari Beras Merah. Jurnal Pangan dan Agroindustri Vol.2 No.3 p.65-75.

Soekarto, T. S. 1985. Penilaian Organoleptik untuk Industri Pangan dan Hasil Pertanian. Bharata Karya. Jakarta. 
Soekotjo, S. 2003. Proses Pembuatan Minuman Probiotik. Program Studi Teknologi Industri Pertanian, Jurusan Agroindustri, Fakultas Teknologi Pertanian, Institut Teknologi Indonesia. Serpong.

Srinivas, D., BK. Mital. And S.K.Garg. 1990. Utlition of sugars by Lactobacillusacidophilus strain. Internasional Journal of Food Microbiology, 10,51-58.

Sudarmadji, S. 1984. Prosedur Analisa untuk Bahan Makanan Pertanian, Edisi ke tiga. Yogyakarta, Liberty.

Susanti, Ida, Retno W. Kusumaningtyas, dan Fatum Illaningtyas. 2007. Uji Sifat Probiotik Bakteri Asam Laktat sebagai Kandidat Bahan Pangan Fungsional. Jurnal Teknologi dan Industri Pangan Vol. 18 (2): 89-95.

Susanto, Wahono Hadi dan Bagus Rakhmad Setyohadi. 2011. Pengaruh Varietas Apel (Malus sylvestris) dan Waktu Fermentasi oleh Khamir Saccharomyces cerivisiae sebagai Perlakuan Pra-pengolahan terhadap Karakteristik Sirup. Jurnal Teknologi Pertanian Vol. 12 No. 3 [Desember 2011] 135-142.

Susilorini, T. E. dan M. E. Sawitri. 2006. Produk Olahan Susu. Cetakan I, Penebar Swadaya, Jakarta.

Syarif, R dan A. Irawati. 1988. Pengolahan Bahan Pangan. Mediyatama Sarana Perkasa. Jakarta.

Umam, M. Faizul, Rohula Utami dan Esti Widowati. 2012. Kajian Karakteristik Minuman Sinbiotik Pisang Kepok (Musa paradisiaca forma typical) dengan Menggunakan Starter Lactobacillus acidophillus IFO 13951 DAN Bifidobacterium longum ATCC 15707. Jurnal Teknosains Pangan Vol.1 No.1.

Vinderola, C. G., P. M. Guemoide, T. Delgado, J.A. Reinheimer and C.G. de los Reyes-Gavilan. 2000. Characteristics of Carbonated Fermented Milk and Survival of Probiotik Bacteria. International Dairy Journal, 10, 213-220.
Voltz, M., dan Beckett, S. T. 1997. Sensory of Chocolate. Presented at the ZDS Chocolate Technology Conference at Anuga Food Technology. Hal. 49.

Wahyudi, A. dan S. Samsundari. 2008. Bugar dengan Susu Fermentasi. UMM Press. Malang.

Widiyaningsih, Endang Nur. 2011. Peran Probiotik untuk Kesehatan. Jurnal Kesehatan, ISSN 1979-7621, Vol. 4, No. 1, 14-20.

Widowati, S. dan Misgiyarta. 2003. Efektivitas Bakteri Asam Laktat (BAL) dalam Pembuatan Produk Fermentasi Berbasis Protein / Susu Nabati. Balai Penelitian Bioteknologi \& Sumberdaya Genetik Pertanian.

Winarno, F.G. 2004. Kimia Pangan dan Gizi. PT. Gramedia Pustaka Tama. Jakarta.

Winarno. 1997. Kesehatan dan Nutrisi yang Terkandung di dalam Bakteri Asam Laktat. http: //www. wikimedia.org/wiki/Lactobacillus _plantarum. Diakses tanggal 05 April 2015.

Winarno, F. G., I. E. Fernandez. 2007. Susu dan Produk Fermentasinya. M-brio press, Bogor.

Wu, X., G. Cai and R. L. Prior. 2002. Absorption and Metabolism of Anthocyanins in Elderly Women after Consumption of Elderberry or Blueberry. Journal of Nutrition 132: 1865-1871.

Yang, Z. 2000. Antimicrobial Compounds And Extracellular Polysaccharides Produced By Lactic Acid Bacteria:Structure and Properties. Department of Food Technology University of Helsinki.

$\mathrm{Yu}$ R. J and E. J. Van Scott. Hydroxycarboxylic acid, $N$-acetylamino sugars, and $\mathrm{N}$-acetylamino acids. Skinmed., 2002; 1 (2): 117-22.

Yudianto, David dan Joni Kusnadi. 2012. Studi Aktivitas Antibakteri Minuman Fermentasi Whey Keju dari Lactobacillus plantarum B2 dan Lactobacillus bulgaricus (Kajian Konsentrasi $\left(\mathrm{NH}_{4}\right)_{2} \mathrm{HPO}_{4}$ dan Sukrosa). 
Jurusan Teknologi Hasil Pertanian Universitas Brawijaya. Surabaya.

Yuliana, Ike, Rodesia M. Roza dan Atria Martina. 2014. Isolasi dan Seleksi Bakteri Asam Laktat dari Yoghurt Kemasan yang Bersifat Antibakteri terhadap Escherichia coli dan Salmonella typhi. Program Studi Biologi, FMIPA UR, Pekanbaru.

Yusmarini dan R. Efendi. 2004. Evaluasi Mutu Soygurt yang Dibuat dengan Penambahan Beberapa Jenis Gula. Jurnal Natur Indonesia, 6 : 104-110.

Zeikus, J. Gregory and Eric A. Johnson. 1991. Mixed Cultures in Biotechnology. McGraw-Hill. Michigan. 